\title{
DEFINING THE OFFICE: \\ JOHN MARSHALL AS CHIEF JUSTICE
}

\section{CHARLES F. HOBSON ${ }^{\dagger}$}

Credit for making the United States Supreme Court a significant player in the American scheme of government has been attributed to the masterful leadership of John Marshall, Chief Justice of the United States from 1801 to 1835 . By the latter year, the Supreme Court had acquired a kind of parity with Congress and the Executive that it did not possess in 1801. Central to this development was the Court's appropriation of the Constitution as its special preserve. Marshall and his brethren built up the Court's institutional strength by successfully asserting a claim to expound the Constitution and apply it as law in the ordinary course of adjudication. Although the Chief Justice's contribution to this enterprise far exceeded his proportional share as a single Justice, scholarship has long since exploded the myth of a heroic Marshall who dominated the Supreme Court by the sheer force of his individual genius and will. Such a myth ignores the historical reality that Marshall's success as Chief Justice resulted from the interplay between his exceptional leadership abilities and the peculiar circumstances of time and place that allowed those abilities to flourish and have effect. "A great man," Oliver Wendell Holmes famously said, "represents a great ganglion in the nerves of society, or, to vary the figure, a strategic point in the campaign of history, and part of his greatness consists in his being there." ${ }^{1}$ Marshall, in short, was the right man in the right place at the right time.

\section{MARSHALL's BACKGROUND AND PERSONAL QUALITIES}

Marshall brought with him a sterling résumé acquired as a soldier, state legislator, lawyer, diplomat, member of Congress, and secretary of state. Indeed, his life and career prior to 1801 seemed specially designed to prepare him for the office of Chief Justice of the United

\footnotetext{
${ }^{\dagger}$ Editor, The Papers of John Marshall, and resident scholar, College of William and Mary School of Law.

${ }^{1}$ Oliver Wendell Holmes, John Marshall, in JAMEs Bradley ThaYer, Oliver Wendell Holmes, AND FeliX Frankfurter ON JOHN MARShall 129, 131 (Philip B. Kurland ed., 1967) [hereinafter THAYER, HOLMES, AND FrANKFURTER ON MARSHALL].
} 
States. As a Continental Army officer who saw combat during the War of Independence, Marshall experienced firsthand the privations and sufferings of his fellow soldiers and gained a visceral understanding of the meaning of a weak central government. In the crucible of war, the future Chief Justice forged the nationalist principles and beliefs that he carried with him through life. The war also marked him for life as a member of the special fraternity of Revolutionary veterans, to which many of his fellow Justices also belonged. The camaraderie of a "band of brothers" formed no small part of the bond uniting the Chief Justice and his associates. ${ }^{2}$

After the war, as a legislator and lawyer, Marshall pursued what amounted to an advanced course in public and constitutional law. Most important was his service in the Virginia ratification convention of 1788, a brilliant assembly whose debates constituted the most exhaustive contemporary examination of the Constitution next to The Federalist. His presence in the company of such luminaries as James Madison, Patrick Henry, and George Mason at this defining and clarifying constitutional moment left an indelible mark. It impressed him with a deep conviction that the Constitution decisively broke with the past by establishing a national government to replace a league of sovereign states. At the same time he recognized that antifederalism was by no means a spent political force but would continue to pose a formidable challenge to his own understanding of the constitutional settlement of $1788 .^{3}$

During the 1790s, Marshall emerged as an occasional but effective advocate for the Federalist administrations of George Washington and John Adams. Most notable in this regard was his defense of the constitutionality of the controversial commercial treaty with Great Britain (the Jay Treaty) while serving in the Virginia legislature in $1795 .{ }^{4}$ Soon after, he made his only appearance as a lawyer in the Supreme Court, representing Virginia debtors in the "British debts" case of Ware v. Hylton. ${ }^{5}$ He lost, but he acquitted himself well by demonstrating a mastery of the law of nations and skill in constitutional argumen-

${ }^{2}$ R. Kent Newmyer, Supreme Court Justice Joseph StOry: Statesman OF The Old RePUblic 82 (1985); JEAN EDWARD SMITH, JOHN MARShall: DEFINER OF A NATION 395, 402-04 (1996).

${ }^{3}$ Charles F. Hobson, The Great Chief Justice: John Marshall and the Rule OF LAW 4 (Wilson Carey McWilliams \& Lance Banning eds., 1996); SMITH, supra note 2, at $142-43$.

${ }^{4}$ SMITH, supra note 2, at 180-81.

${ }^{5} 3$ U.S. (3 Dall.) 199 (1796). 
tation. He further demonstrated his expertise in the law of nations in 1797 and 1798 on a diplomatic mission to France. His dispatches defending American honor and dignity against the insulting behavior of the French catapulted him to the status of national hero. ${ }^{6}$ Marshall's greatest forensic effort prior to becoming Chief Justice was his speech to Congress in March 1800 defending the President's extradition power under the treaty with Great Britain. ${ }^{7}$ This speech displayed the qualities of a judicial pronouncement in the "grand style" that became Marshall's hallmark. President Adams brought Marshall soon thereafter into his cabinet as secretary of state. During his brief tenure in that office, Marshall further distinguished himself with a statement of American foreign policy whose magisterial tone and clear expression were characteristic of his great decisions. ${ }^{8}$ In nominating Marshall to be Chief Justice in January 1801, Adams selected a person whose mastery of public and constitutional law gained him the immediate respect and deference of his fellow Justices. Already a statesman of great renown, Marshall raised the Court's prestige from the moment he donned the robe.

Along with a wealth of experience, Marshall possessed attributes of intellect, learning, and personality that were ideally suited to leading a small assemblage of individual Justices and molding them into a collective entity that spoke with a single authoritative voice. He had a first-class mind, with keen powers of logic, analysis, and generalization that enabled him to master complex legal issues with quick and discerning comprehension. On first encountering the Chief Justice in 1808 , Joseph Story observed a "vigorous and powerful" intelligence, who "examines the intricacies of a subject with calm and persevering circumspection, and unravels the mysteries with irresistible acuteness." Two decades spent in close company as the Chief Justice's associate only confirmed this first impression. "In strength, and depth,

\footnotetext{
${ }^{6}$ For a discussion of Marshall's mission to France and his ensuing hero's welcome home, see SMITH, supra note 2, at 192-237.

${ }^{7}$ John Marshall, Speech in the House of Representatives of the United States (Mar. 7, 1800), reprinted in 4 THE PAPERS OF JOHN MARSHALl 82 (Charles T. Cullen ed., 1984) [hereinafter 4 MARSHALL PAPERS].

${ }^{8}$ See Letter from John Marshall to Rufus King (Sept. 20, 1800), in 4 MARSHALL PAPERS, supra note 7, at 283 (conveying concerns regarding British aggression); see also SMITH, supra note 2, at 273-74 (analyzing this letter).

${ }^{9}$ Letter from Joseph Story to Samuel P.P. Fay, Esq. (Feb. 25, 1808), in 1 LIFE AND LETTERS OF JOSEPH STORY 166, 167 (William W. Story ed., 1851) [hereinafter LIFE AND LETTERS].
} 
and comprehensiveness of mind," Story wrote in Marshall's eulogy, "it would be difficult to name his superior." 10

Marshall's effectiveness as a leader did not depend on being the most learned lawyer on the Court; that honor clearly went to Story, who was a one-man publishing industry of legal treatises and commentaries. Marshall, to be sure, possessed a knowledge of legal science equal to his high judicial station, but his peculiar strength was mastery of general principles rather than "technical, or recondite learning." 11 As Story wrote, Marshall "loved to expatiate upon the theory of equity; to gather up the expansive doctrines of commercial jurisprudence; and to give a rational cast even to the most subtile dogmas of the common law." ${ }^{12}$ Confident enough in his own abilities and knowledge, he could more than hold his own with those of greater learning. He was not afraid to admit ignorance, to seek enlightenment from the lawyers who argued in his courtroom and from colleagues who sat with him on the bench. Indeed, an engaging intellectual humility allowed Marshall to turn his lack of "juridical learning" to his advantage by acknowledging and deferring to his colleagues' superior knowledge. $^{13}$ He earned their trust and respect not by flattery or cajolery but by a genuine desire to draw on their particular expertise. This had the desired effect of making each associate feel as if his views mattered, as if he were an integral part of a common enterprise.

Marshall's abundant charm, sociability, kindness, and unaffected modesty also served him well. At his behest, the Justices lodged together during Term time. In this informal boardinghouse setting that seamlessly mixed official business with the pleasures of social life, Marshall enjoyed the full play of his captivating personality. Having grown up as the oldest of fifteen children, Marshall was predisposed toward moderation and accommodation, to being agreeable, and willing to suppress his individual will in the interests of achieving familial harmony. These qualities proved useful in managing his "family" of brother Justices.

Marshall was also blessed with a robust physical constitution, formed from a rugged, active youth spent in the salubrious climate of the Virginia Piedmont and strengthened from military service during

${ }^{10}$ Joseph Story, Life, Character, and Services of Chief Justice Marshall, in THE MiscellaneOus WRitings OF JOSEPH STORY 639, 685 (William W. Story ed., Boston, Charles C. Little \& James Brown, 1852).

${ }^{11} I d$. at 693 .

${ }^{12} I d$. at $693-94$.

${ }^{13} I d$. at 693 . 
the War of Independence. He carried with him through life the habits and discipline of a soldier. He remained the light infantry officer, the veteran of the camp and march, who could endure the hardship and discomfort of travel, often in primitive conditions. Supreme Court Justices in those days traveled frequently and far, not only sitting in Washington, but also holding circuit courts throughout the country. Marshall's circuit took him to Raleigh, North Carolina, twice a year. Life on the road took its toll on the Justices' health, but Marshall seemed to thrive on it.

Marshall literally was always there, never missing a Supreme Court Term in thirty-five years. He was almost always the first Justice to arrive in Washington. Except for being laid up nearly two weeks by an injury from a fall during the 1824 Term, he never missed a day in court. He arrived a few days late for the 1830 Term because of his attendance at the Virginia Convention of 1829. During the 1826 Term he "had a pretty severe attack of the influenza," which did not keep him from attending court. ${ }^{14}$ Until his death, Marshall's most serious health crisis occurred in the fall of 1831, when he underwent surgery in Philadelphia for the removal of bladder stones. The operation was a complete success, and he recovered in time to hold his November circuit in Richmond. ${ }^{15}$ In 1833, Story reported that the venerable Chief Justice, then seventy-seven, was "in excellent health, never better, and as firm and robust in mind as in body." ${ }^{16}$ His daily routine during Term time was to rise early and walk several miles before getting down to business at an hour early enough that his colleagues might still be fast asleep. ${ }^{17}$ Not until 1835 did Marshall show obvious signs of physical decline, though his intellectual powers remained intact. Clearly, his physical and mental vigor enabled him to perform at the highest level in court, conference, and those solitary morning hours spent reading the day's cases and writing opinions.

Given the daunting challenge that faced him in 1801, Marshall's acceptance of his commission bespoke confidence that he was up to

\footnotetext{
${ }^{14}$ Letter from John Marshall to Mary W. Marshall (Feb. 12, 1826), in 10 THE PAPERS OF JOHN MARSHALl 273, 273 (Charles F. Hobson ed., 2000) [hereinafter 10 MARSHALL PAPERS].

${ }^{15} 12$ The PAPERS OF JOHN MARShall 105, 105-09 (Charles F. Hobson ed., forthcoming 2006) [hereinafter 12 MARSHALL PAPERS].

${ }^{16}$ Letter from Joseph Story to Charles Sumner (Feb. 6, 1833), in 2 LIFE AND LETTERS, supra note 9, at 119, 120.

${ }^{17}$ Letter from John Marshall to Mary W. Marshall (Mar. 7, 1830), in 11 THE PAPERS OF JOHN MARSHALl 353, 353 (Charles F. Hobson ed., 2002) [hereinafter 11 MARSHALL PAPERS].
} 
the job and aspiration to achieve renown as a jurist comparable, say, to that of Lord Mansfield, the great English judge. Marshall fused personal ambition and desire for fame with the institutional potential of the Supreme Court and the office of Chief Justice. He was imbued with a sense of mission to make judicial power an effective instrument of governance in the federal system established by the Constitution. This animating higher purpose no doubt served him well in motivating his associates and instilling an institutional esprit de corps.

\section{The MARShall CoURT}

Over the course of thirty-five years, Chief Justice Marshall remained while other Justices came and went. He had to adjust to changes resulting from personnel turnover and shifting political circumstances. The Marshall Court falls into three more or less distinct periods: (1) a first decade of "crisis" followed by gradual accommodation; (2) the "golden years" from 1811 to about 1824, in which the Court reached its peak as a champion of constitutional nationalism; and (3) a final decade of partial retreat and accommodation in response to states' rights opposition to federal power and a new political order represented by Jacksonian democracy.

\section{A. The Marshall Court, 1801-1810}

Marshall joined a Court consisting entirely of Federalists, who remained in the majority until 1810. During his first four years the Chief and his brethren were embroiled in conflict with the administration of Thomas Jefferson. This was the so-called "judiciary crisis," featuring, among other episodes, the enactment of a judiciary act by the expiring Federalist Congress early in 1801, the repeal of that act by the new Republican Congress in 1802, and the "mandamus case" of Marbury v. Madison ${ }^{18}$ in 1803. The ways in which Chief Justice Marshall led the Court through this critical period set the tone and established patterns that persisted throughout his tenure.

The prospects for the federal judiciary were scarcely auspicious in 1801. In the high political excitement accompanying the Republican electoral victory, the judiciary had become the focal point of the victorious party's resentment and mistrust. Memories were fresh of the federal courts' vigorous enforcement of the Adams administration's efforts to suppress internal dissent during the war crisis of 1798-1799,

${ }^{18} 5$ U.S. (1 Cranch) 137 (1803). 
most conspicuously in prosecuting, fining, and jailing Republican newspaper editors on indictments brought under the notorious Sedition Act. ${ }^{19}$ Federal judges had also rendered themselves obnoxious by delivering grand jury charges that intemperately denounced opposition to government and exhorted the citizenry to support the administration's policies. ${ }^{20}$ In the eyes of Republicans, the judiciary had relinquished all semblance of independence and impartiality and had become a tool of the executive and an instrument of party politics. ${ }^{21}$

Marshall's immediate goal in 1801 was to repair the federal judiciary's damaged reputation by making a strategic retreat from the aggressive, partisan posture it had lately exhibited. The change of administration made such a retreat advisable, and happily for this purpose the new Chief Justice was a man of prudence and moderate political temperament. However, things got worse before they got better. At the very moment that Marshall was confirmed as Chief Justice, the lame-duck Federalist Congress passed a judiciary act creating a host of new federal circuit court judgeships, which were promptly filled by Adams's appointees. Republicans cried foul at what appeared to be a brazen attempt by the defeated party to perpetuate its control of government through the judiciary. ${ }^{22}$ Shortly thereafter, a Federalist-appointed justice of the peace for the District of Columbia sued for a writ of mandamus in the Supreme Court for delivery of his commission, which had been withheld by the Jefferson administration. Taken together, these events brought the judiciary to the brink of crisis, creating a severe test for the new Chief Justice.

In December 1801, the Supreme Court agreed to hear the mandamus action brought by William Marbury and assigned the case to be argued during the next Term. Three months later, irritated by what it perceived to be an unwarranted judicial intrusion into executive matters, the Republican majority in Congress secured the repeal of the Judiciary Act of 1801. The repeal and a subsequent judiciary act adopted in April 1802 restored the former system by which circuit courts were composed of Supreme Court Justices and judges of the United States district courts. This new legislation also provided for an

${ }^{19}$ William R. Casto, The Supreme Court in the Early Republic: The Chief JUSTICESHIPS OF JOHN JAY AND OLIVER ELLSWORTH 165-69 (1995).

${ }^{20} I d$. at 126-29.

${ }^{21} 1$ Charles Warren, The Supreme COURT in United States History 163-65 (1926).

${ }^{22}$ Charles F. Hobson, John Marshall, the Mandamus Case, and the Judiciary Crisis, 1801-1803, 72 GEO. WASH. L. REV. 289, 291-92 (2003). 
annual Term of the Supreme Court, commencing the first Monday in February. Consequently, the Court would not meet again until February 1803, when Marbury's case was to be argued. ${ }^{23}$

Before that case could be heard, the Supreme Court Justices in the spring of 1802 faced a dilemma: should they hold the circuit courts established by the recent legislation? By attending their circuits, they would signify their acquiescence to Congress's authority to reinstate circuit riding by Supreme Court Justices. Chief Justice Marshall himself doubted the constitutionality of the measure, believing that Supreme Court Justices could not perform circuit duty without separate and distinct commissions as circuit judges. Unable to consult personally with his brethren because of the postponement of the Court's next Term, Marshall initiated a correspondence with Justices William Paterson, William Cushing, Bushrod Washington, and Samuel Chase. $^{24}$ In these letters, Marshall set forth his doubts, while adding that it was "my duty \& my inclination in this as in all other cases to be bound by the opinion of the majority of the Judges." ${ }^{25}$ Upon learning that a majority of the Justices considered this question to be fully settled by the practice of riding circuit from 1789 to 1801, the Chief Justice readily assented, remarking that "policy dictates this decision to us all." ${ }^{26}$

The Justices averted a showdown by attending their circuit courts in the fall of 1802. They further demonstrated their intention not to become instruments of party politics by steadfastly resisting attempts by Federalist lawyers to deny the authority of the courts to hear cases continued from the former circuit courts established under the repealed 1801 act. One such attempt occurred in Marshall's own circuit in Richmond in December 1802, when a defendant pleaded that the Judiciary Act of 1802 was unconstitutional and void. The Chief Justice rejected this plea in the case of Stuart $v$. Laird, ${ }^{27}$ which was appealed to the Supreme Court and argued during the February 1803 Term. In a

${ }^{23} I d$. at $294-96$.

${ }^{24} I d$. at $296-97$.

${ }^{25}$ Letter from John Marshall to William Paterson (Apr. 19, 1802), in 6 THE PAPERS OF JOHN MARSHALL 108, 108-09 (Charles F. Hobson ed., 1990) [hereinafter 6 MARSHALL PAPERS].

${ }^{26}$ Letter from John Marshall to William Paterson (May 3, 1802), in 6 MARSHALL PAPERS, supra note 25 , at 117,117 . Only Justice Chase was inclined to refuse to ride circuit. Letter from Samuel Chase to John Marshall (Apr. 24, 1802), in 6 MARSHALL PAPERS, supra note 25, at 109, 113-16.

${ }^{27} 5$ U.S. (1 Cranch) 299 (1803). 
brief opinion, Justice Paterson, speaking for the Court, reaffirmed the decision the Justices had reached the preceding spring. ${ }^{28}$

This episode provided a revealing preview of Marshall's collegial style of leadership of the Supreme Court. In his communications with his fellow Justices, Marshall demonstrated an openness to argument and persuasion and a willingness to subordinate his own views if necessary to obtain a single opinion of the Court-attributes that served him well during the next three decades. The repeal crisis also brought forth Marshall's essential moderation and his pragmatic recognition that "good policy" at times should supersede doctrinaire adherence to strict law. Marshall was instinctively cautious and acutely aware of the judiciary's weakness and vulnerability. His overriding concern during his first years as Chief Justice was to insure the judiciary's survival by directing a prudent retreat away from "politics" and into the comfort zone of "law." Only in the safety of that refuge, Marshall recognized early on, could the judiciary not simply hope to weather the immediate storm but also in the longer run to build up its institutional strength and elevate its status and authority.

The separation of law and politics was also the broader issue in Marbury v. Madison, ${ }^{29}$ even though in the short run that case further implicated the Supreme Court in the partisan warfare of the day. In announcing the Court's opinion in February 1803, Chief Justice Marshall affirmed that Marbury had a legal right to his commission but ultimately denied relief on the ground that the Court lacked jurisdiction to issue a writ of mandamus to government officers. ${ }^{30}$ Although a provision of an act of Congress authorized such actions, the Chief Justice pronounced that provision unconstitutional as purporting to enlarge the Supreme Court's original jurisdiction beyond that prescribed by Article III of the Constitution. ${ }^{31}$

The refusal of the mandamus was thus a victory for the Jefferson administration, but at the time the opinion only exacerbated Republican opposition to the judiciary. Their anger was directed at the Court's presumption in deciding the merits of the case, gratuitously charging the administration with acting unlawfully, before ultimately

${ }^{28}$ Id. at 309.

${ }^{29} 5$ U.S. (1 Cranch) 137 (1803).

${ }^{30}$ Id. at $162,175-76$.

31 Id. at 173-80; see also U.S. CONST. art. III, $§ 2$, cl. 2 ("In all Cases affecting Ambassadors, other public Ministers and Consuls, and those in which a State shall be Party, the supreme Court shall have original Jurisdiction.”). 
denying jurisdiction to hear the case. ${ }^{32}$ They were not mollified by Marshall's assurances that the Court's province was solely to decide on issues of individual rights and not to inquire into executive conduct where the executive had discretion to act. However, by denying jurisdiction, Marshall managed to uphold the claims of judicial power without having to issue an order commanding the executive to deliver the commission.

By contrast, the Court's assumption of authority to declare a law of Congress unconstitutional provoked scarcely a murmur at the time. Here again Marshall acted opportunely to assert the judiciary's "duty" to regard the Constitution as law and to disallow legislative acts deemed to be repugnant to it. ${ }^{33}$ A broad spectrum of American opinion in 1803 did not dispute this proposition, and Marshall appealed to this consensus in making the case for what came to be known as "judicial review." " ${ }^{34}$ It helped enormously that Marbury was a case of judicial self-denial, of refusing jurisdiction that Congress had given, so that the Court could present itself as a high-minded, impartial tribunal concerned solely with expounding law. Considered together, Marbury v. Madison and Stuart v. Laird amounted to a declaration of independence by the Supreme Court, an announcement of withdrawal from the political realm. On the one hand, the Court refused to capitulate to the Republican administration's contention that executive conduct was completely exempt from judicial oversight; on the other, in pointedly refusing to reconsider the constitutionality of circuit riding by Supreme Court Justices, it resisted pressure to carry out Federalist Party goals.

The horizon was not yet clear, however, as radical Republicans were bent on using impeachment as a means of removing federal judges. A prime target was the irascible, overbearing Justice Chase, reviled for his partisan and intemperate conduct of sedition and treason trials during the Adams administration and more recently for a grand jury charge denouncing the Jefferson administration and expressing contempt for democracy. In March 1805, the Senate failed to convict Chase by the necessary two-thirds majority. His acquittal signified a triumph of moderation within the Republican ranks that in time brought about a rapprochement between the political and judi-

\footnotetext{
${ }^{32} 1$ WARREN, supra note 21, at 244-45, 248-53.

33 Marbury, 5 U.S. (1 Cranch) at 178.

341 WARREN, supra note 21 , at 255-68.
} 
cial branches. $^{35}$ By 1807 , Jefferson had three of his own appointeesWilliam Johnson, Brockholst Livingston, and Thomas Todd-on the Supreme Court. A clear indication of how far accommodation had progressed was the Madison administration's response to a Supreme Court decision of 1809 ordering the Commonwealth of Pennsylvania to abide by a lower federal court decree. When the Commonwealth resisted, President Madison reminded the Governor that the federal executive was legally bound to carry into effect any federal court decree, "where opposition may be made to it." the $1830 \mathrm{~s}$, accommodation-if not harmony-characterized interdepartmental relations between the judiciary and the executive department.

\section{B. The Marshall Court, 1811-1824}

Following the deaths of Cushing and Chase, President Madison appointed Joseph Story and Gabriel Duvall in 1811 as Associate Justices. Of the seven Justices on the Supreme Court (a seventh seat had been added in 1807), five had been appointed by Republican Presidents. But the Republican Justices were all political moderates, as were Marshall and Washington, the only Federalist holdovers. Far from being a source of division, party affiliations were virtually meaningless. More important were forces binding them together: their common heritage as members of the Revolutionary generation, their devotion to the Constitution and union, their shared values as members of a common law legal culture, and their implicit belief that law and courts were vital to the functioning of government and society. ${ }^{37}$ All were caught up in the surge of nationalism that rolled over the United States during and after the War of 1812. Chief Justice Marshall tapped into these unifying elements to consolidate the Court's status and authority as guardian and interpreter of the Constitution. With no further changes in personnel taking place until 1823, the Marshall Court during the next dozen years achieved its highest degree of internal unity and stability and made its most enduring contributions to American constitutional law.

${ }^{35}$ Richard E. Ellis, The JefFERsonian Crisis: COURTS AND POLITICS IN THE YOUNG REPUBLIC 76-82, 96-107 (1971).

${ }^{36}$ George Lee Haskins \& Herbert A. Johnson, Foundations of Power: John MARSHALL, 1801-15, pt. 1, at 330 (The Oliver Wendell Holmes Devise History of the Supreme Court of the United States, vol. 2, Paul A. Freund ed., 1981); see also id. at 322-31 (discussing the incident).

${ }^{37}$ SMITH, supra note 2, at 402-04. 
In this enterprise, no Chief Justice was more fortunate than Marshall in having a colleague as talented, energetic, and devoted as Joseph Story. From the time he took his seat on the Court, Story devoted his fertile mind and boundless energy to the tasks of championing the jurisdiction of the federal courts, expansively reading the powers conferred upon the general government, and vigorously enforcing the Constitution's protections of contractual and property rights. In these judicial endeavors, he was the Chief Justice's ablest and most effective associate. ${ }^{38}$ On their first meeting in 1808, Story took an instant liking to Marshall, impressed by his "great subtilty of mind" and captivated by his "laugh," which was "too hearty for an intriguer." 39 During more than two decades of service together on the Court, they formed an intimate friendship founded on mutual affection and compatibility of beliefs and principles-most notably in their common devotion to nationalism. The alliance between the Virginian and the New Englander was key to the effectiveness of the Marshall Court. "Without your vigorous and powerful cooperation," the Chief wrote his younger associate in 1831, "I should be in despair, and think the 'ship must be given up." 40

Story was one of two Associate Justices who achieved a reputation in his own right while serving on the Marshall Court. The other was William Johnson of South Carolina, who prided himself on being an independent jurist who spoke his own mind, as reflected in numerous concurring and dissenting opinions given over a period of thirty years (he has been called the Supreme Court's "first dissenter"). ${ }^{41}$ Appointed by Jefferson, Johnson in fact was so independent as to be unpredictable. Contrary to Jefferson's expectations, for example, the South Carolinian advocated implied powers and supported an ample reading of Congress's power over commerce. His doctrinal disagreements with the Marshall Court consensus arose from his greater faith in legislative government, both state and federal, and a corresponding suspicion of expansive judicial power. Temperamental, quick to take offense, and disinclined to ingratiate himself with his associates, Johnson had something of an "outsider" personality. He posed no threat

38 See generally NEWMYER, supra note 2, at 74-114.

${ }^{39}$ Letter from Joseph Story to Samuel P.P. Fay, supra note 9, at 167.

${ }^{40}$ Letter from John Marshall to Joseph Story (Nov. 10, 1831), in 12 MARSHALL PAPERS, supra note 15, at 124, 124.

41 See generally Donald G. MORgan, Justice William Johnson: The First Dissenter: The CAREer And Constitutional Philosophy OF A JefFersonian JUdGe (1954). 
as one who could win adherents or form his own coalition on the Court. Marshall, as with all his associates, treated Johnson with respect and sensitivity. A measure of the Chief Justice's skill in bringing this eccentric brother on board as a team player, if only temporarily, was Johnson's silent approval of the nationalizing opinions handed down by the Marshall Court during these years. ${ }^{42}$

In a series of unanimous or near-unanimous decisions, the Supreme Court affirmed Congress's implied powers, broadly interpreted Congress's power to regulate commerce, struck down state laws that conflicted with the principle of federal supremacy or that violated the Constitution's prohibition against laws impairing the obligation of contract, asserted broad jurisdiction to decide cases arising under the Constitution and laws of the United States, and sustained its appellate power over the state judiciaries. Most of these cases originated in the state courts and came to the Supreme Court by writ of error, as provided by section 25 of the Judiciary Act of 1789 . $^{43}$ Section 25 empowered the Court to hear appeals from a state's highest court in cases that involved a "federal" question-that is, when a state court denied a party's right claimed under the Federal Constitution or a federal law or treaty. ${ }^{44}$

In the 1816 case of Martin v. Hunter's Lessee, ${ }^{45}$ the first important constitutional case after the War of 1812, Story established his credentials as a judicial nationalist, filling in for the Chief Justice, who had disqualified himself from the case. Story's opinion made the definitive case for the Supreme Court's appellate jurisdiction over the state courts under section 25 of the Judiciary Act. ${ }^{46}$ In 1819, three major decisions invalidating state laws provided a stunning display of constitutional nationalism. In Trustees of Dartmouth College v. Woodward, the Court held that the colonial charter incorporating Dartmouth College was a contract protected by the Constitution and struck down New Hampshire's laws converting the New England college into a statecontrolled university. ${ }^{47}$ The Court also applied the Contract Clause to

\footnotetext{
${ }^{42}$ Donald G. Morgan, The Origin of Supreme Court Dissent, 10 WM. \& MARY Q. 353, 367-68 (1953); see also HERBERT A. JOHNSON, THE CHIEF JUSTICESHIP OF JOHN Marshall, 1801-1835, at 32-33 (1997); R. Kent NewMYER, JOHN MARSHALl AND THE HEROIC AGE OF THE SUPREME COURT 404 (2001).

Ch. 20, § 25, 1 Stat. 73, 85-87.

${ }^{44}$ Id.

${ }^{45} 14$ U.S. (1 Wheat.) 304 (1816).

${ }^{46} I d$. at $327-51$.

${ }^{47} 17$ U.S. (4 Wheat.) 518, 651-54 (1819).
} 
strike down a New York insolvency law in Sturges $v$. Crowninshield. ${ }^{48}$ Marshall spoke for the Court in these two cases and in the third of that Term, McCulloch $v$. Maryland, proclaiming the doctrine of implied powers to uphold Congress's power to incorporate a national bank and invoking the Supremacy Clause to deny a state's right to tax the bank. ${ }^{49}$

Two years later, in Cohens $v$. Virginia, Chief Justice Marshall expansively read the judiciary article as conferring on the Supreme Court broad jurisdiction to decide cases involving the conflicting powers of the federal and state governments. ${ }^{50}$ Green $v$. Biddle, first decided in 1821 and reaffirmed in 1823, invalidated Kentucky's land laws allowing compensation to settlers who had been ousted by nonresident titleholders. $^{51}$ Story wrote, for the Court, that the compact by which Kentucky had separated from Virginia was a contract protected against impairment by state legislation. ${ }^{52}$ The high tide of constitutional nationalism continued through the 1824 Term, with Gibbons v. Ogden ${ }^{53}$ and Osborn v. Bank of the United States. ${ }^{54}$ In the former, Marshall expounded the Commerce Clause for the first time in voiding New York's laws establishing a monopoly on steam navigation of the state's waterways. ${ }^{55}$ In the latter, the Chief Justice nullified Ohio's attempt to tax the national bank while affirming the federal judiciary's broad jurisdiction to provide front-line protection to federal instrumentalities. ${ }^{56}$

Such judicial activism on behalf of nationalism aroused the forces of antifederalism and states' rights, generating a torrent of impassioned denunciations of the Supreme Court and its Chief Justice. By then, however, the federal judiciary was much less isolated and vulnerable than it had been during the crisis years of 1801 to 1805 . Although posing a continual challenge to the exercise of judicial power, states' rights opposition to the Court was sporadic and local, never gaining ascendancy in the country at large. A state or region that felt particularly aggrieved by a Supreme Court decision found little sup-

${ }^{48} 17$ U.S. (4 Wheat.) 122 (1819).

${ }^{49} 17$ U.S. (4 Wheat.) 316, 406-37 (1819).

${ }^{50} 19$ U.S. (6 Wheat.) 264, 398-400 (1821).

5121 U.S. (8 Wheat.) 1 (1823).

${ }^{52} I d$. at $15-17$.

5322 U.S. (9 Wheat.) 1 (1824).

5422 U.S. (9 Wheat.) 738 (1824).

${ }^{55}$ Gibbons, 22 U.S. (9 Wheat.) at 221.

${ }^{56}$ Osborn, 22 U.S. (9 Wheat.) at 867-68. 
port elsewhere. Nonetheless, a number of proposals were introduced in Congress to curb the Court's powers such as repealing section 25, amending the Constitution to give appellate jurisdiction to the Senate when a state was a party, and enlarging the number of Justices on the Court to ten and requiring the concurrence of seven to pass on the constitutionality of state and federal acts. ${ }^{57}$ That none of these measures succeeded testified both to the American people's underlying agreement to preserve the integrity of the Supreme Court and to Chief Justice Marshall's leadership in transforming it into a tribunal of high prestige and authority.

\section{The Marshall Court, 1825-1835}

Until the mid-1820s, all of the important cases that required the Supreme Court to perform the delicate task of determining the limits on state powers had resulted in an abridgment of state sovereignty. Mindful that these decisions had stirred up opposition to its assumed role as arbiter of the federal system, the Marshall Court during its last decade shifted into a lower gear, away from the high nationalism of its golden years, to a more accommodating posture with respect to the states. In large measure this was a concession to changed circumstances, to a new political reality in the nation at large and on the Court itself. For his part, Chief Justice Marshall proved sufficiently flexible to embrace political expediency so far as necessary to maintain the Court's vitality and effectiveness.

The internal unity of the Court began to erode during these years, as reflected by the increase in separate and dissenting opinions. In truth, the so-called Marshall Court "monolith" had always been more of a façade held together by the Chief's expert hand. ${ }^{58}$ On a Court that was changing with the addition of new members, Marshall was unable to maintain his former influence and control. With Livingston's death in 1823, Smith Thompson joined the Court during the 1824 Term. Todd died in 1826, replaced by Robert Trimble, who served only one Term before he died in 1828. Washington died the next year, leaving two vacancies. President Andrew Jackson filled these with John McLean and Henry Baldwin, both of whom took their seats at the 1830 Term. $^{59}$

${ }^{57} 1$ WARREN, supra note 21 , at 652-85.

${ }^{58}$ Morgan, supra note 42; Donald M. Roper, Judicial Unanimity and the Marshall Court-A Road to Reappraisal, 9 AM. J. LEGAL HIST. 118 (1965).

${ }^{59}$ Morgan, supra note 42 , at 375 n. 81 . 
Earlier, in 1824, Johnson emerged from his temporary silence to announce that he would henceforth give his own opinion in major constitutional cases. ${ }^{60}$ Thompson and Trimble also served notice that they would follow an independent course. With Johnson and Washington, they were part of a majority of four that, in the 1827 case of Ogden $v$. Saunders, upheld the validity of state bankruptcy laws that operated prospectively on contracts. ${ }^{61}$ For the first and only time in his tenure, Chief Justice Marshall was compelled to dissent in a constitutional case. ${ }^{62}$

The Court continued to issue decisions nullifying state laws, but its strong nationalist voice was now muffled by dissents. ${ }^{63}$ In the 1830 case of Craig v. Missouri, for example, Marshall could muster only a bare majority to rule that state loan office certificates were "bills of credit" prohibited by the Constitution. ${ }^{64}$ Johnson, Thompson, and McLean wrote separate dissents in that case, leaving Marshall to fret about the future prospects of maintaining supervision over state courts under section 25 jurisdiction. ${ }^{65}$ What the Chief Justice called a "revolutionary spirit" also manifested itself in the rupture of the Justices' communal living arrangements, which for so many years had served to promote harmony as well as efficiency. ${ }^{66}$

Ironically, whatever unity the Court now displayed occurred in cases upholding state laws. In the 1829 case of Willson v. Black Bird Creek Marsh Co., a unanimous Court declared that a state law authorizing construction of a dam across a navigable creek was a legitimate exercise of regulatory power that did not interfere with Congress's "dormant" power to regulate commerce. ${ }^{67}$ The Court also unanimously agreed, in 1830 in Providence Bank $v$. Billings, that a state law imposing a tax on corporations was not repugnant to the Contract

${ }^{60} I d$. at 373 . Johnson made this announcement in his concurring opinion in Gibbons, 22 U.S. (9 Wheat.) at 222-23.

${ }^{61} 25$ U.S. (12 Wheat.) 213, 313, 331 (1827).

${ }^{62}$ Id. at 332 (Marshall, C.J., dissenting).

${ }^{63}$ See, e.g., Weston v. Charleston, 27 U.S. (2 Pet.) 449 (1829) (holding unconstitutional a municipal tax on stock issued for loans to the United States, with Justice Johnson dissenting); Brown v. Maryland, 25 U.S. (12 Wheat.) 419 (1827) (striking down a state law that required the licensing of importers of foreign articles, with Justice Thompson dissenting).

${ }^{64} 29$ U.S. (4 Pet.) 410, 433 (1830)

${ }^{65}$ Letter from John Marshall to Joseph Story (Oct. 15, 1830), in 11 MARSHALL PAPERS, supra note 17 , at $384,384$.

${ }^{66}$ Letter from John Marshall to Joseph Story (May 3, 1831), in 12 MARSHALL PAPERS, supra note 15 , at $62,62-63$.

${ }^{67} 27$ U.S. (2 Pet.) 245, 252 (1829). 
Clause. ${ }^{68}$ Finally, in the 1833 case of Barron $v$. Baltimore, ${ }^{69}$ the Marshall Court's last constitutional case, the Justices were of one mind in rejecting a Baltimore wharf owner's attempt to invoke the "takings" clause of the Fifth Amendment to obtain compensation for damage to his property. The Bill of Rights, said Marshall, was intended to restrict the federal government, not the state governments. ${ }^{70}$ As spokesman for these unanimous concessions to state sovereignty, Chief Justice Marshall showed himself to be a pragmatic jurist who valued unity above doctrinal purity.

Despite this shifting tide, Marshall still had the clout to rally his brethren for an emphatically nationalist opinion in the 1832 case of Worcester v. Georgia, holding that Georgia's laws extending sovereignty over the Cherokee Indians were repugnant to the Federal Constitution, laws, and treaties governing Indian affairs. ${ }^{71}$ In championing the rights of the Cherokee, however, the Supreme Court encountered resistance to its authority not only from a single state but also from the Jackson administration, which supported Georgia's sovereign pretensions. Once again, as in its early years, the Marshall Court confronted a hostile President with a popular mandate. However, the threatened clash between the Court and President Jackson over the enforcement of Worcester never materialized, as the administration successfully negotiated a compromise that resolved the case without further legal proceedings-a compromise in which the Cherokee were the losers. ${ }^{72}$

The last major decision of the Marshall Court, Worcester underscored the judiciary's impotence in the face of a determined political majority. The Court could not reverse the administration's Indian policy and could not do anything for the Cherokee beyond affirming the tribe's legal and constitutional rights. Although demonstrating that the judiciary was indeed the "weakest branch," the case in a real sense also heralded the Supreme Court's maturation as an independent institution of the federal government. Contrary to popular myth, the Jackson administration was not spoiling for a fight with the Marshall Court. The President did not defy its order, nor did he wish to be placed in a situation that would compel him to choose between

${ }^{6} 29$ U.S. (4 Pet.) 514, 564-65 (1830).

${ }^{69} 32$ U.S. (7 Pet.) 243 (1833).

${ }^{70} I d$. at $250-51$.

${ }^{71} 31$ U.S. (6 Pet.) 515, 562-63 (1832).

${ }^{72}$ Joseph C. Burke, The Cherokee Cases: A Study in Law, Politics, and Morality, 21 Stan. L. REv. 500, $520-31$ (1969); Edwin A. Miles, After John Marshall's Decision: Worcester v. Georgia and the Nullification Crisis, 39 J. S. HIST. 519 (1973). 
compliance or defiance. $^{73}$ For their part, Marshall and his brethren had no desire to issue an order to the executive. Yet they incurred the risk of confrontation in order to avoid a greater risk-loss of institutional pride and identity. To have remained silent in the face of a manifest violation of the Constitution and federal laws would have seriously compromised the Supreme Court's claim to be the guardian and expositor of the nation's fundamental law, if not the keeper of the nation's moral conscience. As Story remarked, the Justices could "wash their hands clean of the iniquity of oppressing the Indians, and disregarding their rights."

Soon after the Chief Justice's death in 1835, John Quincy Adams recorded a tribute that, coming from a former President and perceptive observer of the national scene, spoke volumes for how far the Supreme Court and the office of Chief Justice had risen in importance during the preceding three decades. Marshall, wrote Adams,

\begin{abstract}
was one of the most eminent men that this country has ever produced... . All constitutional governments are flexible things; and as the Supreme Judicial Court is the tribunal of last resort for the construction of the Constitution and the laws, the office of Chief Justice of that Court is a station of the highest trust, of the deepest responsibility, and of influence far more extensive than that of the President of the United States. . . Marshall, by the ascendency of his genius, by the amenity of his deportment, and by the imperturbable command of his temper, has given a permanent and systematic character to the decisions of the Court, and settled many great constitutional questions favorably to the continuance of the Union. ${ }^{75}$
\end{abstract}

\title{
III. Marshall as Chief Justice
}

John Marshall defined the office of Chief Justice in various ways. His primary responsibility was to preside over the Supreme Court's annual meeting in Washington. From the outset, he sought to make the Court both a collegial and an efficient institution by bringing the Justices together under the same roof. Instead of going their separate ways after court adjourned each day, the Justices reconvened at their boardinghouse to consult about cases. The boardinghouse confer-

${ }^{73}$ See generally Miles, supra note 72.

${ }^{74}$ Letter from Joseph Story to Sarah W. Story (Mar. 4, 1832), in 2 LIFE AND LETTERS, supra note 9 , at 86,87 .

75 MEMOIRS OF JOHN QUINCY AdAMS: COMPRISING PORTIONS OF His DiARY FROM 1795 TO 1848, at 243 (AMS Press 1970) (1876). 
ence was Marshall's best opportunity to exercise leadership, notably in persuading his brethren to sign on to a single opinion of the Court.

Marshall's responsibility as Chief Justice was not confined to the Supreme Court. Marshall Court Justices probably spent more judicial time attending their circuit courts than they did in Washington. Because many federal cases began and ended on circuit, Marshall believed it was important that such cases be decided according to uniform principles. To promote this goal on his own circuit, the Chief Justice, when beset by doubts, regularly wrote to his brethren for advice.

Marshall's tenure as Chief Justice commenced at a time of turmoil and crisis for the federal judiciary. Although it survived the early confrontation with the Jefferson administration, the Marshall Court was subject to periodic attacks in subsequent years. No one felt the sting of censure more acutely than Marshall, who willingly assumed the role as the judiciary's chief advocate and defender.

\section{A. Presiding over Court and Conference}

For most of Marshall's tenure, the Supreme Court sat in a basement room of the Capitol below the Senate chamber. The annual Term commenced the first Monday in February (moved to the second Monday in January, beginning in 1827) and continued into the middle of March. Adjournment could not be postponed indefinitely because the Justices had to return home in time to hold their spring circuits. The Court met daily (except Sunday) from eleven to four, hearing arguments that often went on for hours ${ }^{76}$ and could extend over several days. ${ }^{77}$ A rule of court limited the number of lawyers to no more than two for each party. ${ }^{78}$ This rule was suspended, however, in the great bank case of McCulloch $v$. Maryland, ${ }^{79}$ which employed the talents of six distinguished counselors in an argument that extended over nine days. ${ }^{80}$

In sharp contrast to modern Court practice, which restricts oral argument to thirty minutes, during which counsel is frequently interrupted by questions from the bench, in Marshall's day the lawyers were "heard in silence for hours, without being stopped or inter-

\footnotetext{
761 WARREN, supra note 21 , at 467.

77 SMITH, supra note 2, at 292.

78 SuP. CT. R. 23, 26 U.S. (1 Pet.) ix (1828).

7917 U.S. (4 Wheat.) 316 (1819).

${ }^{80} 1$ WARREN, supra note 21 , at 507.
} 
rupted." ${ }^{81}$ At his first Term in 1812, Story noted that the arguments were "excessively prolix and tedious; but generally the subject is exhausted, and it is not very difficult to perceive at the close of the cause, in many cases, where the press of the argument and of the law lies." ${ }^{82}$ The Court heard the lawyers out because they depended on oral arguments for the explication of the issues and authorities on which the case turned. Unlike current practice, counsel did not file comprehensive written briefs in advance of oral argument. Prior to hearing a case, the Justices had only the appellate record, consisting of a transcript of the proceedings in the court below and an abstract of the pleadings, facts, documents, and points of law and fact to be presented. Such statements were often no more than a page or two and did not amount to a coherent legal argument. ${ }^{83}$ Oral argument, then, was essential to understanding all aspects of a case. While the lawyers argued, the Justices took notes in a memorandum book or, as Marshall did, on the flyleaves of the printed record. At the end of the Term, Marshall delivered his accumulated notes to the reporter to use in preparing his report of the arguments. ${ }^{84}$

According to contemporary descriptions, Chief Justice Marshall presided with wisdom, dignity, and impartiality-virtues of the ideal judge-which were accompanied by a self-effacing modesty, benign temper, and kindly manner. He was noted for being "exceedingly kind and courteous to the Bar," listening to their arguments "with the greatest attention." ${ }^{85}$ Story drew the fullest portrait of Marshall in court:

Enter but that hall, and you saw him listening with a quiet, easy dignity to the discussions at the bar; silent, serious, searching; with a keenness of thought, which sophistry could not mislead, or error confuse, or ingenuity delude; with a benignity of aspect, which invited the modest to move on with confidence; with a conscious firmness of purpose, which repressed arrogance, and overawed declamation. You heard him pronounce the opinion of the Court in a low but modulated voice, unfolding in luminous order every topic of argument, trying its strength, and

${ }^{81} I d$. at 467.

${ }^{82}$ Letter from Joseph Story to Samuel P.P. Fay, Esq. (Feb. 24, 1812), in 1 LIFE AND LETTERS, supra note 9, at 215, 215.

${ }^{83}$ R. Kirkland Cozine, The Emergence of Written Appellate Briefs in the NineteenthCentury United States, 38 AM. J. LEG. HIST. 482, 486-87 (1994).

${ }^{84}$ Letter from John Marshall to William Wirt (July 6, 1825), in 10 MARSHALL PAPERS, supra note 14, at 193.

${ }^{85} 1$ WARREN, supra note 21 , at 469. 
measuring its value, until you felt yourself in the presence of the very oracle of the law. ${ }^{86}$

In the conference room, Marshall brought "the same presiding genius, the same kindness, attentiveness, and deference; and yet, when the occasion required, the same power of illustration, the same minuteness of research, the same severity of logic, and the same untiring accuracy in facts and principles." ${ }^{87}$ Here, too, the Chief Justice was a patient and attentive listener, not merely soliciting but demanding arguments- "no judge ever profited more by them," Story remarked. ${ }^{88}$ By careful and alert listening, he quickly and almost intuitively grasped a case's leading principles and the points on which it turned without having a previous acquaintance with "the learning upon which it depended." 89

The conference took place in the boardinghouse, to which the Justices returned after court adjourned at four. As Marshall commented in an 1831 letter, except for attending occasional social events, he spent his evenings "in consultation with the Judges." Upon joining the Court in 1812, Story immediately felt the harmonizing and unifying effects of living with his brethren "in the most frank and unaffected intimacy" and being "all united as one, with a mutual esteem which makes even the labors of Jurisprudence light." ${ }^{91}$ As led by Marshall, the boardinghouse conference was remarkably well adapted to reaching a decision promptly, often, said Story, "in a few hours." ${ }^{92}$ Living and dining together encouraged a frank yet cordial exchange of views, fostered collegiality, and advanced the goal of reaching an opinion of the Court. The Chief was a master at conducting serious business in an atmosphere of conviviality, even mirth. The usually ascetic Justices were known on occasion to stretch their rule of drinking wine only in wet weather. Marshall would sometimes ask "Brother Story" to "step to the window and see if it does not look like rain." And if Story informed him that the sun was "shining brightly," the Chief Justice might reply, "[a]ll the better; for our jurisdiction ex-

${ }^{86}$ Story, supra note 10 , at 692.

${ }^{87}$ Id.

${ }^{88} I d$. at 694

${ }^{89} \mathrm{Id}$.

${ }^{90}$ Letter from John Marshall to Mary W. Marshall (Jan. 30, 1831), in 12 MARSHALL PAPERS, supra note 15, at 15, 16.

${ }^{91}$ Letter from Joseph Story to Samuel P.P. Fay, supra note 82, at 215.

${ }^{92} I d$. at 215-16. 
tends over so large a territory that the doctrine of chances makes it certain that it must be raining somewhere." ${ }^{93}$

Probably at Marshall's direction, if not by his example, the Justices usually came alone to Washington, living pretty much in monastic seclusion from Washington society. This was perhaps yet another way in which Marshall tried to project an image of an independent judiciary composed of serious and sober-minded judges devoted to doing the public's work. They did, to be sure, attend dinners and other social events, but Court business took priority. At one busy Term, the conference met every day except Sunday. Marshall declined an invitation for a Wednesday, explaining that he could not be absent "from our daily consultation without inter[r] upting the course of the business \& arresting its progress." ${ }^{94}$ No one understood better than the Chief Justice the importance of communal living for the efficient conduct of business. Only by adhering to a strict regimen could the Justices hope to get through a docket that became increasingly crowded during and after the War of 1812. Toward the end of his tenure, Marshall encountered difficulty keeping the Justices together, a sign of his diminishing ability to preserve the Court's internal unity. He worried that if the Justices scattered, the consequence would be many undecided cases and "seriatim opinions." 95

\section{B. The Opinion of the Court}

The single majority opinion had been the Marshall Court's most distinctive practice from the outset, as announced in the 1801 case of Talbot v. Seeman. ${ }^{96}$ In adopting the single opinion, Marshall deliberately departed from the traditional mode of seriatim opinions by each of the Justices, which had prevailed under his predecessors and was also the custom in both the state and English courts. ${ }^{97}$ As precedents

${ }^{93}$ JOSIAH QUINCY, FIGURES OF THE PAST FROM THE LEAVES OF OLD JOURNALS 18990 (4th ed. 1883).

${ }^{94}$ Letter from John Marshall to John Randolph (Mar. 4, 1816), in 8 THE PAPERS OF JOHN MARSHALL 127, 127 (Charles F. Hobson ed., 1995) [hereinafter 8 MARSHALL PAPERS].

${ }^{95}$ Letter from John Marshall to Joseph Story (May 3, 1831), in 12 MARSHALL PAPERS, supra note 15 , at $62,62-63$.

${ }^{96} 5$ U.S. (1 Cranch) 1 (1801); see also SMITH, supra note 2, at 292-93 (discussing the origins of the "Opinion of the Court" practice in the Talbot case).

${ }^{97}$ Under Chief Justice Ellsworth, "By the Court" opinions began to be issued without accompanying opinions by individual Justices. G. Edward White, The Internal Powers of the Chief Justice: The Nineteenth-Century Legacy, 154 U. PA. L. REV. 1463, 1470 (2006). 
for the single opinion practice, Marshall could point to Lord Mansfield, Chief Judge of England's Court of Kings Bench in the late eighteenth century, and to Judge Edmund Pendleton of the Virginia Court of Appeals, before whom the future Chief Justice had argued cases in the 1780s and 1790s. Marshall recognized the advantages of a single statement in imparting weight and authority to the Court's pronouncements, thereby promoting certainty and stability in the law. The public would come to perceive the Court as a unified and independent institution whose judgments were formed by solemn collective deliberation. ${ }^{98}$ The Court would enhance its authority and prestige while the Chief Justice as its spokesman would become the personal embodiment of its stature and dignity. ${ }^{99}$

A telling measure of how quickly and thoroughly Marshall institutionalized the single opinion is that between 1801 and 1804 he delivered the opinion for all the cases in which he sat. ${ }^{100}$ Through the 1807 Term, he spoke for the Court in nearly three-fourths of the reported cases. ${ }^{101}$ During its first decade, the Marshall Court evidently adopted a seniority rule, by which the Chief Justice was the most senior of the Justices by virtue of his commission. ${ }^{102}$ In later years, the Court appears to have abandoned the seniority rule, and the delivery of the majority opinion was distributed among other Justices. Still, the general pattern of Marshall speaking for the Court persisted throughout his tenure. During his last eight terms, he gave the opinion in more than forty percent of the cases. In thirty-five years, he delivered more than 500 of the Court's estimated 1106 reported opinions ${ }^{103}$ and more than sixty percent of the constitutional opinions. ${ }^{10}$

During his first decade as Chief Justice, Marshall's quest for internal unity was made easier by having Associate Justices of his Federalist political persuasion. The "siege" mentality brought on by the judiciary crisis also served to bind the Justices more closely together, promote cohesiveness, and induce them to speak with one voice through the Chief. Some of his colleagues may have been more compliant because age and infirmity had eroded their physical and intellectual

98 SMITH, supra note 2, at 292-93.

99 NEWMYER, supra note 42, at 157.

100 Morgan, supra note 42, at 355.

1016 MARSHALL PAPERS, supra note 25 , at 70.

102 JOHNSON, supra note 42, at 100-01.

103 Morgan, supra note 42, at 363 n.32.

104 Robert G. Seddig, John Marshall and the Origins of Supreme Court Leadership, 36 U. PITT. L. REV. 785, 800 tbl.1 (1975). 
vigor. This was particularly true of Cushing and Paterson, whose best days were behind them. ${ }^{105}$ Along with advancing years, Chase's impeachment ordeal $^{106}$ appears to have chastened him into silence. William Johnson, Jefferson's first appointee, joined the Court in 1804. In a later recollection, he explained the "real cause" of Marshall's dominance: "Cushing was incompetent, Chase could not be got to think or write-Patterson was a slow man and willingly declined the trouble, and the other two judges [Marshall and Washington] you know are commonly estimated as one judge."107 Even discounting Johnson's recollection as overstated, it is fair to say that Marshall was able to take charge so quickly and thoroughly because his associates were disinclined to put up any resistance.

Once firmly established, the single majority opinion survived for the duration of the Marshall Court. It had the effect of projecting unity when in fact the judges were divided. Unless the opinion was said to be "unanimous," the size of the majority was unknown. The internal dynamics of this collegial institution encouraged silent acquiescence by Justices who dissented from the majority. Johnson, who had been accustomed to seriatim opinions as a state court judge, was dissuaded early on from delivering a dissent by "lectures on the indecency of judges cutting at each other." ${ }^{108}$ He accordingly "bent to the current" but "persevered," he wrote in 1822, until the Justices adopted their present policy of appointing "someone to deliver the opinion of the majority," leaving "it to the discretion of the rest of the Judges to record their opinions or not ad libitum." 109 On one occasion, Story suppressed a strong urge to dissent, noting that "Judge Washington thinks (and very correctly) that the habit of delivering dissenting opinions on ordinary occasions weakens the authority of the Court, and is of no public benefit." ${ }^{110}$ Dissenting opinions did occur, to be sure, though usually prefaced with an apology from the Justice for disagreeing with his colleagues. Most of the Marshall Court Justices, including the Chief Justice, dissented at one time or another, with Johnson recording the greatest number of dissents.

${ }^{105}$ JOHNSON, supra note 42, at 100.

${ }^{106}$ See supra note 35 and accompanying text.

${ }^{107}$ Letter from William Johnson to Thomas Jefferson (Dec. 10, 1822), quoted in Morgan, supra note 42, at 369 .

${ }^{108} I d$.

${ }^{109} I d$.

${ }^{110}$ Letter from Joseph Story to Henry Wheaton (Apr. 8, 1818), in 1 LIFE AND LETTERS, supra note 9, at 303-04. 
Although most of the original drafts of Supreme Court opinions for the Marshall years have been lost, the surviving material indicates that Marshall wrote, as well as delivered, the opinions in which he spoke for the Court. Over time, with the steady increase in the number of cases on the docket, the labor of composing the opinion of the Court had to be more widely shared with the other Justices. Up to the end, however, his output was prodigious. In 1834, he delivered thirtytwo opinions (about half the total), the largest number given at any Term during his tenure. ${ }^{111}$ The manuscripts of twenty of these opinions are in his hand; the others are short opinions that were not committed to writing. ${ }^{112}$

Of all the assets that made Marshall a great leader of the Court, perhaps none was as important as his fluency with a pen. He simply had no peer in turning out cogently argued and lucidly written opinions in a timely fashion. In sessions whose duration for most of Marshall's tenure were about a month and a half, the Court had to act expeditiously to produce a decision and opinion in all the cases that were argued. In no small part because of the Chief Justice's facility in writing, the Marshall Court compiled a remarkable record in meeting this goal at every Term. In the great majority of cases, the decision was announced and the opinion given within a week of the close of argument. $^{113}$ The interval was understandably longer for the major constitutional cases, but with the exception of Dartmouth College, ${ }^{114}$ Marshall managed to write and deliver the constitutional opinions during the Term they were argued. McCulloch ${ }^{115}$ regarded by many as Marshall's greatest opinion, was delivered a scant three days after the close of argument. ${ }^{116}$ The short interval between argument and opinion raises questions that cannot be answered with certainty. For example, in McCulloch, did the Justices moot this case in conference and take a preliminary vote while it was still being argued? Did the Chief Justice, once the case's disposition was clear, begin drafting the opin-

111 MARSHALl PAPERS, supra note 15 , at 558-60.

${ }^{112}$ See id. (listing Marshall's opinions for the 1834 Term and indicating those for which a manuscript exists).

${ }^{113}$ Lists of Marshall's Supreme Court opinions, along with the dates of argument and decision, can be found in the appendices of volumes six through twelve of The Papers of John Marshall.

${ }_{114}$ Trs. of Dartmouth Coll. v. Woodward, 17 U.S. (4 Wheat.) 518 (1819).

${ }^{115}$ McCulloch v. Maryland, 17 U.S. (4 Wheat.) 316 (1819).

${ }^{116}$ See 8 MARSHALL PAPERS, supra note 94 , at 396 , for dates of arguments and decisions in Dartmouth College and McCulloch. 
ion before the argument had concluded? ${ }^{117}$ The text of the opinion Marshall pronounced in open court was virtually the same as that published a few months later in the official report. This can be confirmed by comparing the report with the newspaper version published a few days after the opinion was handed down.

How close a vetting did Marshall's draft get from his associates? In 1819, a newspaper critic of McCulloch insinuated that, in the absence of seriatim opinions, the public could not know whether the other Justices approved of the Chief Justice's reasoning. This provoked an indignant reply from Marshall, who under cover of a pseudonym pointed out that

the chief justice never speaks in the singular number, or in his own person, but as the mere organ of the court.... The course of every tribunal must necessarily be, that the opinion which is to be delivered as the opinion of the court, is previously submitted to the consideration of all the judges; and, if any part of the reasoning be disapproved, it must be so modified as to receive the approbation of all, before it can be delivered as the opinion of all. ${ }^{11}$

This evidently did not mean that the Chief Justice circulated his draft among the Justices for their comments, which he then incorporated in a revised draft. It did mean that, at a minimum, the opinion was read to the assembled Justices in conference. ${ }^{120}$ If a Justice raised objections or suggested changes, he most likely aired them at the conference reading. No doubt the Justices gave close scrutiny to constitutional opinions. But, given the constraints of time, in ordinary cases they were not likely to delay matters by insisting on extensive revisions.

If the drafting of the opinion was the responsibility of a single Justice, most often Chief Justice Marshall, must we conclude that this was essentially an individual activity, that the opinion's content "was a matter only for himself and the Court's reporter"? ${ }^{121}$ If the single majority opinion conveyed a misleading impression of unity, it also had the ef-

${ }^{117}$ White suggests affirmative answers to both of these questions. White, supra note 97 , at $1472-73$.

118 See John Marshall, Opinion, DAily NAT'L InTELligenter (Wash., D.C.), Mar. 13, 1819, reprinted in 8 MARSHALL PAPERS, supra note 94, at 259 (providing Marshall's opinion in McCulloch).

119 A Friend to the Union No. I, U.S. GazetTe \& True American (Phila.), Apr. 24, 1819, reprinted in 8 MARSHALL PAPERS, supra note 94, at 287, 290.

${ }^{120}$ See Letter from John Marshall to John M. Patton (Mar. 2, 1831), in 12 MARSHALl PAPERS, supra note 15, at 39 (stating that he had not attended the conference and did not "hear the opinion read except in court").

${ }^{121}$ White, supra note 97 , at 1473. 
fect of magnifying the Chief Justice's role while diminishing that of his associates. It concealed the degree to which the opinion was the product of collective deliberation, of compromise and accommodation. Because this process took place orally, undocumented by any surviving conference memoranda or notes, it has largely been lost to history. Although the boardinghouse conference proceedings cannot be recovered, we can reasonably speculate that Marshall acted somewhat like a committee chair who collected the views of his associates and fashioned a report that reflected the sense of the whole. To assist him, he had the record of the case, the lawyers' abstracts, his notes of the argument, and perhaps notes or memoranda of the conference. If Marshall himself did not take notes during the conference, then Story was a likely candidate to act as recording secretary. Suffice to say there was nothing comparable to the opinion writing process of the modern Court, with its multiple drafts and exchange of memoranda.

At the time of delivery, there was only an original rough draft of the opinion. In response to a newspaper publisher's request to publish Cohens, ${ }^{122}$ Marshall explained that the opinion was "the property of the court" and that he would have to ask his colleagues if they would "part with the original; having no copy." ${ }^{123}$ To a similar request in 1824 for a copy of the opinion in Gibbons, ${ }^{124}$ Marshall again noted that there was no copy and added that

\begin{abstract}
the rough draft has, as will always happen when an opinion on an extensive \& complex question is written without previous arrangement, frequent insertions of argument which are supposed to belong properly to a part which has been passed, in separate papers with letters of reference. Without great care this will lead to blunders in printing of a serious extent. Mr. Wheaton is accustomed to copying our opinions \& will be enabled to be of great service to you should you proceed to print it. ${ }^{125}$
\end{abstract}

In this rough form, with its insertions and deletions, the draft was turned over to the reporter, who then made a fair copy for the printer. Once the opinion was set in type and proofed, the reporter must have, in many instances, destroyed the original or made no spe-

${ }^{122}$ Cohens v. Virginia, 19 U.S. (6 Wheat.) 264 (1821).

${ }^{123}$ Letter from John Marshall to Gales \& Seaton (Mar. 3, 1821), in 9 THE PAPERS OF JOHN MARSHALl 143, 143 (Charles F. Hobson ed., 1998) [hereinafter 9 MARSHALL PAPERS].

${ }^{124}$ Gibbons v. Ogden, 22 U.S. (9 Wheat.) 1 (1824).

${ }^{125}$ Letter from John Marshall to Gales \& Seaton (Mar. 3, 1824), in 10 MARSHALL PAPERS, supra note 14, at 35 . 
cial effort to preserve it. ${ }^{126}$ The Chief Justice took an active interest in the publication of the opinion and in making sure that it was accurately printed. He knew from experience that a newspaper printing of the original manuscript was likely to contain errors. After reading the newspaper rendition of Cohens, he drew up a list of typographical and other errors for Wheaton to correct before publishing his report, carefully noting the page, column, paragraph, and line where the errors had occurred. ${ }^{127}$

Between the reading of the opinion and its publication in the reports, there was an opportunity to make alterations. Story, for example, read over Marshall's Dartmouth College opinion before publication and suggested deleting a passage concerning the exercise of judicial functions by legislatures. Marshall readily consented to Story's "editing" in a way that underscored his implicit trust in his junior brother's judgment: "I would myself prefer that it should stand as you suggest; but were it otherwise, your opinion in a case on which I felt no particular solicitude, would be decisive with me." ${ }^{128}$ After seeing the opinion in Cohens as published in the newspapers "attacked with a degree of virulence superior even to that which was employed in the Bank question," ${ }^{129}$ Marshall instructed Wheaton to add a note to his report showing that the case had come properly before the Court under section 25 of the Judiciary Act. ${ }^{130}$ In his original draft of Worcester, ${ }^{131}$ Marshall omitted a sentence he intended as the conclusion to the argument. Three weeks after delivering the opinion, he supplied the omission to the reporter, who incorporated it into the report. ${ }^{132}$

The only opportunity for Marshall and his brethren to write opinions or prepare memoranda in advance of the Court's conference was

\footnotetext{
${ }^{126}$ Not until 1834 were original opinions of the Supreme Court preserved as part of the official archival record. 6 MARSHALL PAPERS, supra note 25, at 70.

${ }^{127}$ Letter from John Marshall to Henry Wheaton (Mar. 24, 1821), in 9 MARSHALL PAPERS, supra note 123, at 147, 148.

${ }^{128}$ Letter from John Marshall to Joseph Story (Apr. 28, 1819), in 8 MARSHALL PAPERS, supra note 94, at 309, 309.

${ }^{129}$ Letter from John Marshall to Henry Wheaton (June 2, 1821), in 9 MARSHALL PAPERS, supra note 123, at 150, 150.

${ }^{130}$ Id. Marshall claimed the critics had accused the Court of "'feigning' a case for the purpose [of] ushering prematurely on the public their political dogmas." Id. (alteration in original). Wheaton received Marshall's note in time for insertion into the official report. See Cohens v. Virginia, 19 U.S. (6 Wheat.) 264, 376 n.a (1821) (reflecting the addition).

13131 U.S. (6 Pet.) 515 (1832).

${ }^{132}$ See Letter from John Marshall to Richard Peters (Mar. 23, 1832), in 12 MARSHALl PAPERS, supra note 15, at 188, 189; see also Worcester, 31 U.S. (6 Pet.) at 562.
} 
in cases held under advisement from one Term to the next. One constitutional case, Dartmouth College, ${ }^{133}$ fell into this category. The argument of that case concluded on March 12, 1818. The next day Chief Justice Marshall ordered the case to be continued to the 1819 Term, noting that some Justices had not come to an opinion and those who had formed opinions did not agree. The expectation was that the case would be reargued in 1819, but instead Marshall pronounced the Court's opinion on February 2, the second day of the Term. ${ }^{134}$ Presumably, he drafted the opinion before he came to Washington and presented it to the Justices in conference on February 1.

Under Marshall's tight management of the docket, the Court did not have many cases under advisement. Such cases elicited occasional comment in his correspondence, which is otherwise relatively sparse on Supreme Court matters. The important militia case of Houston $v$. Moore $^{135}$ in 1820, for example, was argued during the 1819 Term and held over. In response to a letter from Story in the summer of 1819, Marshall said he "had never thought of preparing an opinion" in that case, adding: "That is committed to you \& cannot be in better hands. I shall just sketch my ideas for the purpose of examining them more closely but shall not prepare a regular opinion." ${ }^{136}$ Writing to Story in 1823 on another case under advisement, the Chief Justice noted that he had "come with very considerable doubt" to a different conclusion from Story's and hoped he would prepare an opinion. ${ }^{137}$ "Should the court concur with you," said Marshall, "I shall be far from regretting it for my opinion in this case is not one of those in which I feel such confidence as to regret its not prevailing." ${ }^{138}$ Again, in 1829, Marshall asked Story to turn his attention "to the two great cases we have under advisement." One of these, the 1830 case of Inglis $v$. Trustees of the Sailor's Snug Harbour, ${ }^{139}$ had come up from New York. The Chief Justice was anxious that Story prepare an opinion because he himself would not be able to give it the attention it deserved. He presumed Justice Thompson (of New York) would write an opinion, "but if the majority of the court should not concur with him, it will be necessary

13317 U.S. (4 Wheat.) 518 (1819).

1348 MARSHALL PAPERS, supra note 94, at 219-20.

13518 U.S. (5 Wheat.) 1 (1820).

${ }^{136}$ Letter from John Marshall to Joseph Story (July 13, 1819), in 8 MARSHALL PAPERS, supra note 94, at 352, 353.

${ }^{137}$ Letter from John Marshall to Joseph Story (Nov. 24, 1823), in 9 MARsHALL PAPERS, supra note 123, at 346, 346.

${ }^{138} I d$. (footnote omitted).

13928 U.S. (3 Pet.) 99 (1830). 
that preparation should be made for such an event." ${ }^{140}$ These comments provide further testimony that opinion writing on the Marshall Court was a cooperative enterprise.

\section{Maintaining Uniformity on Circuit}

The Justices of the Marshall Court also sat as trial judges of the U.S. circuit courts, which they attended twice yearly-each spring and fall. Chief Justice Marshall attended the Fifth Circuit, composed of Virginia and North Carolina, holding court in Richmond and Raleigh. When he discussed judicial matters in his correspondence, Marshall most often sought advice about new and difficult questions arising on circuit. Most of these cases, in turn, were ones that he could not carry to the Supreme Court because they neither met the jurisdictional minimum of two thousand dollars nor were eligible for a certificate of division between the two judges constituting the circuit court. In one such case, Marshall remarked that he would have carried it to the Supreme Court, but he did not have "the privilege of dividing the court when alone \& as the sum is only about $1800 \$$ it must abide by my decision." ${ }^{141}$ The Chief Justice sought guidance not merely to decide the particular case but to promote the goals of consistency and uniformity in similar cases arising in the various circuits. As he explained in a letter soliciting advice on the perplexing questions raised in the 1807 treason case of Aaron Burr, Marshall would have preferred a full consultation with his brethren on points "on which a contrariety of opinion ought not to prevail in the different circuits, but which cannot easily be carried before the supreme court." ${ }^{142}$ Aware of a judge's unwillingness to "commit himself by an opinion on a case not before him \& on which he has heard no argument," the Chief Justice urged that this consideration be outweighed by the "strong \& general repug-

${ }^{140}$ Letter from John Marshall to Joseph Story (July 3, 1829), in 11 MarshaLL PAPERS, supra note 17, at 263, 263, 264 n.4.

${ }^{141}$ Letter from John Marshall to Joseph Story (July 13, 1819), in 8 MARSHALL PAPERS, supra note 94 , at 352,352 . In stating that he did not have "the privilege of dividing the court when alone," Marshall meant that in the absence of U.S. District Judge St. George Tucker, he could not use the certificate of division as a means of sending the case up to the Supreme Court. The certificate of division was provided by the Judiciary Act of 1802. When both judges of the circuit court were present, they could "agree to disagree" in difficult cases and refer them to the Supreme Court. G. EDWARD White, The Marshall Court And Cultural Change 1815-1835, at 173-74 (1988).

${ }^{142}$ Letter from John Marshall to William Cushing (June 29, 1807), in 7 THE PAPERS OF JOHN MARSHALl 60, 60 (Charles F. Hobson ed., 1993) [hereinafter 7 MARSHALL PAPERS]. 
nance to giving contradictory decisions on the same points" on circuit. $^{143}$

On many subsequent occasions Marshall was not shy about asking advice. These letters provide ample confirmation of his modest and deferential style of leadership, his ready acceptance of his colleagues' better-informed judgment, and his willingness to subordinate his views for the sake of uniformity. They also illuminate his close professional and personal bond with Story, on whose advice he placed the greatest trust and confidence. Story and Washington were the only Justices with whom Marshall regularly corresponded, but most of his letters to Washington concerned their joint projects to publish a revised edition of Marshall's Life of George Washington and to prepare an edition of General Washington's correspondence.

The immensely learned Story could throw light on any legal subject but was of particular service in admiralty questions. Not having practiced in admiralty courts and sitting on a circuit that had less admiralty business than any other on the Atlantic, Marshall was admittedly "not versed" in that area of law. ${ }^{14}$ After obtaining his younger colleague's views on one such case, Marshall replied that he would decide it "in conformity with your reasoning. It is I think perfectly sound; \& were this even questionable, the practice of the courts ought to be uniform." 145 In another case, involving a claim for salvage on a vessel recaptured from pirates, Marshall wondered if the question had been decided elsewhere. If not, he wrote Story, "you will greatly oblige me by your sentiments on it, as I know that you are more au fait on these questions than I am." ${ }^{146}$ On another occasion he confessed to having "so little experience in admiralty proceedings that I sometimes doubt in cases which are probably quite of common occurrence and are thought very plain by those who have much practice of that description." ${ }^{147}$ The case in question was a libel in admiralty by one who had furnished supplies to a vessel not within the Court's jurisdiction. Was "such a suit sustainable?" asked the Chief Justice. ${ }^{148}$ Mar-

${ }^{143}$ Id. at 62.

${ }^{144}$ Letter from John Marshall to Joseph Story (May 27, 1819), in 8 MARSHALL PAPERS, supra note 94, at 313, 314.

${ }^{145}$ Letter from John Marshall to Joseph Story (July 13, 1819), in 8 MARSHALL PAPERS, supra note 94, at 352, 352 (footnote omitted).

${ }^{146}$ Letter from John Marshall to Joseph Story (Dec. 9, 1823), in 9 MARSHALL PAPERS, supra note 123, at 353, 354.

${ }^{147}$ Letter from John Marshall to Joseph Story (May 23, 1831), in 12 MARSHALL PAPERS, supra note 15 , at $67,67$.

${ }^{148}$ Id. at 68. 
shall subsequently adopted Story's opinion sustaining the jurisdiction, "though in doing so I have reversed the decree of my brother Barbour." 149

In a piracy case heard on circuit in 1823, the defendant's counsel moved to have a mixed jury of foreigners and citizens. Such juries could be ordered under state law, but there was no federal law to this effect. Marshall and U.S. District Judge St. George Tucker ultimately granted the motion, though the Chief Justice had doubts. He explained to Story that Tucker "was very clear in favor of the application," and added that the bar had informed them of a New York circuit case in which Justice Thompson had directed a mixed jury:

Being unwilling in a capital case to reject the application of the prisoner
by a division of the court, where I felt doubt myself, \& where an associate
Justice had determined the question in favor of the application I con-
curred in directing the jury. It is a point on which the practice ought
certainly to be uniform \& I propose to suggest it to the Judges in Febru-
ary next.

In the meantime, he wished Story to turn his mind to the subject. ${ }^{151}$

Marshall also appealed to his New England brother for aid in resolving puzzling commercial questions, such as one concerning the law of principal and agent in a suit between Virginia merchants and New York merchants. The Chief Justice searched all his books on the subject but could "find nothing applicable to this case." ${ }^{\text {"52 }}$ Marshall, who off the bench was a farmer, then added, "You commercial men are familiar with these questions-to us agriculturists they are at least novel." ${ }^{153}$ Other legal queries on which the Chief Justice solicited information concerned the respective liabilities of the creditors of an insolvent public debtor, ${ }^{154}$ a demurrer to evidence in a case against a whiskey distiller, ${ }^{155}$ and the sufficiency of process served on the presi-

${ }^{149}$ Letter from John Marshall to Joseph Story (June 26, 1831), in 12 MARSHALL PAPERS, supra note 15, at 93, 93.

${ }^{150}$ Letter from John Marshall to Joseph Story (Nov. 24, 1823), in 9 MARSHALL PAPERS, supra note 123, at $346,346$.

${ }^{151} I d$.

${ }^{152}$ Letter from John Marshall to Joseph Story (Dec. 11, 1827), in 11 MARSHALL PAPERS, supra note 17, at 60, 61 .

${ }^{153} I d$.

${ }^{154}$ Letter from John Marshall to Joseph Story (June 15, 1821), in 9 MARSHALL PAPERS, supra note 123, at 167, 167.

${ }^{155}$ Letter from John Marshall to Joseph Story (Sept. 18, 1821), in 9 MARSHALL PAPERS, supra note 123, at 183, 184-85. 
dent of a state bank. ${ }^{156}$ On one rare occasion, Marshall was the dispenser rather than seeker of advice. Replying to a question from Washington, he tentatively ventured the opinion that a bill of exchange drawn in one state of the union on a person residing in another state would be considered an inland rather than a foreign bill. ${ }^{157}$ Eight years later, however, Washington for the Supreme Court held that such bills were foreign. ${ }^{158}$

\section{Defender of the Judiciary}

Aside from performing the formal and official duties of officepresiding in court and conference and writing and delivering opinions-Marshall believed that as Chief Justice he had a broader responsibility to act as a statesman: to be the representative, advocate, and defender of the federal judiciary. He performed this role in various ways and settings, but always with resolute seriousness and sometimes with impassioned fervor.

From the beginning, he seized the opportunity to gain the public's respect and good will at sessions of the U.S. circuit court. Whatever direct contact most Americans had with Supreme Court Justices in the early nineteenth century occurred during the sitting of the circuits. Few were able to observe the Supreme Court in Washington, but many more could hear a Supreme Court Justice deliver a jury charge or pronounce a judgment on circuit. Twice each year the citizens of Richmond and Raleigh had a chance to see Chief Justice Marshall in action.

Because criminal business was always first on the docket, circuit court sessions opened with the convening of the grand jury and the delivery of the charge. During the 1790s, federal grand jury charges had been occasions for circuit-riding Supreme Court Justices to make major speeches that not only instructed the jurors concerning the criminal law but also addressed broader issues of law and politics. The Justices regarded it as their solemn duty to inculcate political virtue among the people, to act as "republican schoolmasters" by teaching

${ }^{156}$ Letter from John Marshall to Bushrod Washington (May 28, 1822), in 9 MARSHALL PAPERS, supra note 123, at 203, 203.

${ }^{157}$ Letter from John Marshall to Bushrod Washington (July 13, 1821), in 9 MARSHALL PAPERS, supra note 123, at 180, 180.

${ }^{158}$ See Buckner v. Finley, 27 U.S. (2 Pet.) 586, 590 (1829) (“[B]ills drawn in one of these states, upon persons living in any other of them, partake of the character of foreign bills, and ought so to be treated."). 
the principles of patriotism and good citizenship. ${ }^{159}$ It was customary for their charges to be published in the newspapers. As party conflicts between Federalists and Republicans heated up during that decade, however, federal grand jury charges began to cross the line from defense of government to defense of the administration in power and denunciation of its political opponents. ${ }^{160}$

Mindful of the extent to which partisan harangues on circuit (Chase was a prime offender) had sullied the federal judiciary's reputation, Chief Justice Marshall gave early notice of a more cautious judicial posture in his own grand jury charges. He intended to use these occasions to foster his policy of withdrawing the judiciary from the political arena and confining its activities to matters strictly judicial. In Richmond in May 1803, for example, the Chief Justice drew praise from the leading Republican newspaper for delivering "a pertinent charge to the Grand Jury, strictly within the limits of his official duty." To contrast this charge, the newspaper continued, "with the infamous political degeneracy which marked every sentence of that lately delivered by Judge Chase in Baltimore, would be to condemn the latter as a shameless dereliction." ${ }^{161}$ Earlier, on his first North Carolina circuit, Marshall delivered a charge that was praised for its appropriateness in fully explaining the grand jurors' duties "without the least political intermixture." ${ }^{162}$ The Chief Justice not only stuck to the judicial straight and narrow but took the further precaution of refusing newspaper publication of his charges. In declining one paper's request for a copy of his "elegant and learned charge," Marshall explained "that he had laid it down as a rule from which he did not intend to depart, not to allow his charges to be published." ${ }^{163}$

Over the course of many years, Chief Justice Marshall, whether sitting in Washington, Richmond, or Raleigh, sought to build up the people's trust in the federal judiciary as an impartial institution solely concerned with deciding cases according to strict legal principles. Nowhere was this task more difficult than in his native state of Virginia, which throughout his tenure was firmly under the sway of states'

${ }^{159}$ See Ralph Lerner, The Supreme Court as Republican Schoolmaster, 1967 SUP. CT. REV. 127, 156 ("Members of the pre-Marshall Supreme Court while on circuit may fairly be called 'teachers to the citizenry."”).

${ }^{160}$ CASTO, supra note 19, at 126-29.

${ }^{161}$ EXAMINER (Richmond, Va.), May 25, 1803.

${ }^{162}$ RAleigh REG. \& N.C. STATE GAZETTE, Jan. 4, 1803, at 3.

${ }^{163}$ N.C. MineRVA, Jan. 4, 1803, at 3. 
rights Republican orthodoxy. After the early crisis of 1801 to $1805,{ }^{164}$ the most serious challenges to federal judicial authority arose in Virginia. In 1815, the Virginia Court of Appeals refused to acknowledge the U.S. Supreme Court's mandate in an 1813 case, declaring section 25 of the Judiciary Act unconstitutional. ${ }^{165}$ This prompted the Supreme Court to reaffirm, in Martin v. Hunter's Lessee, its constitutional authority to revise state court judgments involving a federal question. ${ }^{166}$ States' rights Virginians were still smarting from Martin when Marshall in 1819 delivered the Court's opinion in McCulloch v. Maryland. ${ }^{167}$ From the moment it was published, Virginia newspapers unleashed a torrent of hostile criticism of the opinion as a constructive usurpation of the rights of the states that would soon result in the imposition of a consolidated national government. "This opinion must be controverted and exposed," one editorialist wrote. "Virginia has proved herself the uniform friend of state rights-again, she is called upon to come forth!" 168

These attacks so alarmed Marshall that he undertook an extrajudicial defense of McCulloch in a series of newspaper essays under the noms de plume "A Friend to the Union" and "A Friend of the Constitution." ${ }^{169}$ He was motivated by growing apprehension that the animosity generated by McCulloch was merely the start of a broader assault on the Constitution and the Union itself aimed at its most vulnerable point, the federal judiciary. "Hostility to the Union, must cease to be guided by its usual skill," he wrote in his first "Friend to the Union" essay, "when it fails to select the weakest department as that through which a breach may be effected." ${ }^{\text {"70 }}$ His overriding fear was that the unleashing of the "antifederal spirit of Virginia" ${ }^{171}$ would produce defiant resolutions by the Virginia General Assembly similar to those of 1798 and 1799 in response to the Alien and Sedition Acts.

164 See supra Part II.A.

${ }^{165}$ Hunter v. Martin, 18 Va. (4 Munf.) 1, 58 (1815).

16614 U.S. (1 Wheat.) 304, 342-51 (1816).

16717 U.S. (4 Wheat.) 316 (1819).

168 Editorial Note, Essays Defending McCulloch v. Maryland, in 8 MARSHALL PAPERS, supra note 94, at 282, 282 (citation omitted).

${ }^{169}$ The newspaper essays attacking McCulloch and Marshall's essays defending the opinion are collected in JOHN MARSHALL'S DEFENSE OF MCCULLOCH V. MARYLAND (Gerald Gunther ed., 1969). Marshall's essays can also be found in 8 MARSHALL PAPERS, supra note 94 , at 287-308, 318-34, 335-52, 353-63.

${ }^{170}$ A Friend to the Union, No. I (Apr. 24, 1819), reprinted in 8 MARSHALL PAPERS, supra note 94 , at 287, 288.

${ }^{171}$ Letter from John Marshall to Joseph Story (Apr. 28, 1819), in 8 MARSHALL PAPERS, supra note 94, at 309, 309. 
The consequence might be the emasculation of the Supreme Court and other measures that would effectively dismantle the federal government.

To protect his anonymity, Marshall sent his essays to his friend and colleague Justice Washington, who arranged for their publication. He wrote them in response to pieces by "Amphictyon" and "Hampden." Hampden, as Marshall and everyone in Virginia knew, was the redoubtable Spencer Roane, eminent judge of Virginia's Court of Appeals, an opponent of the Constitution in 1788, and an outspoken champion of states' rights in resisting the Supreme Court's mandate in 1813. In Hampden (Roane), the Chief Justice recognized a bold and formidable opponent who went far beyond Amphictyon in impeaching the integrity and legitimacy of the judiciary department. What must have particularly rankled Marshall was Hampden's contention that the Supreme Court had no jurisdiction to decide cases involving a clash of powers between the state and general governments. In all, he wrote nine numbers of "A Friend of the Constitution" to refute Roane's charges. ${ }^{172}$

Marshall carried his defense of the judiciary beyond the pages of the newspapers. To make sure his message got to the right people, he directed his essays to be placed "in the hands of some respectable members" of the Virginia legislature. ${ }^{173}$ As he feared, resolutions condemning the bank decision were introduced in the House of Delegates, one of which instructed the state's senators and representatives to procure a constitutional amendment creating a separate tribunal for deciding all questions involving a conflict between the powers of the federal and state governments. However, the legislature closed its session without taking any official action, an indication that Marshall's defense had its effect. ${ }^{174}$

The Supreme Court's vulnerability to a hostile Congress, particularly in the form of proposals to reduce its appellate jurisdiction, was a source of perennial concern to Marshall. In 1823, he worked quietly and brilliantly behind the scenes to defeat one such measure. In reaction to the Court's invalidation of Kentucky's occupying claimant laws in Green v. Biddle, ${ }^{175}$ a Kentucky senator introduced legislation that would have increased the number of Supreme Court Justices to ten

${ }^{172}$ Editorial Note, supra note 168, at 284-86.

${ }^{173}$ Letter from John Marshall to Bushrod Washington (ca. June 28, 1819), in 8 MARSHALL PAPERS, supra note 94, at 317, 317.

${ }^{174}$ Editorial Note, supra note 168 , at 286.

17521 U.S. (8 Wheat.) 1 (1823). 
and required the concurrence of at least seven Justices in cases involving the validity of state laws or acts of Congress. ${ }^{176}$ This proposal elicited from Marshall a private communication to his friend Henry Clay, the influential Speaker of the House of Representatives. Clay, as the Chief Justice well understood, had reason to be displeased with the ruling in Green, having argued in favor of the validity of Kentucky's laws in the Supreme Court. ${ }^{177}$ Marshall accordingly composed his letter with great tact and sensitivity-and a little humor as well. Assuming "the privilege of age to utter wise sayings somewhat like proverbs . . . as a substitute for that powerful and convincing argument which it has lost the faculty of making," the Chief Justice observed that "it is among the most dangerous things in legislation to enact a general law of great and extensive influence to effect a particular object." ${ }^{\text {178 }} \mathrm{He}$ then went on to suggest the "serious inconvenience" that would result "from a very numerous supreme court." More alarming was the requirement of a supermajority to decide constitutional questions, which in effect would prevent the Court from exercising judicial review of legislation. A "conscientious legislator" could never assent to a measure that would defeat an object obviously contemplated by the Constitution: "It is I think difficult to read that instrument attentively without feeling the conviction that it intends to provide a tribunal for every case of collision between itself and a law, so far as such case can assume a form for judicial enquiry ...." ${ }^{180}$ The Chief Justice's timely intervention no doubt had its effect. Thanks in no small part to his superb political skills, neither this proposal nor other attempts to curb the Court's power were enacted into law during his chief justiceship.

The Chief Justice's role as the judiciary's champion took yet another form in 1829, when Marshall, at the age of seventy-four, served as a delegate to the Virginia constitutional convention. Here he proved to be a tenacious defender of judicial independence, showing no disposition to compromise when he perceived a threat to this vital principle. As chairman of the Judiciary Committee, he presented a report providing for judicial tenure during good behavior, accompanied by a clause specifying that "no modification or abolition of any

1761 WARREN, supra note 21 , at 663-64.

${ }^{177}$ Id. at 638-39.

${ }^{178}$ Letter from John Marshall to Henry Clay (Dec. 22, 1823), in 9 MARSHALL PAPERS, supra note 123 , at $365,365$.

${ }^{179} I d$.

${ }^{180} I d$. at $365-66$. 
Court shall be construed to deprive any Judge thereof of this office." 181 Marshall's motive was to guard against a possible construction founded on Congress's 1802 repeal of the Judiciary Act of 1801. The repeal had abolished the federal circuit courts, composed of sixteen new judgeships, established by the 1801 act. Marshall strenuously denied that the 1802 repeal was an authoritative precedent for the legislature's power to abolish the office of a judge by abolishing the judge's court. ${ }^{182}$

This clause encountered much resistance, requiring all of Marshall's legislative skill and eloquence to preserve it. No doubt, too, his venerable dignity as Chief Justice of the United States helped him win support. In speeches he patiently tried to explain why an uncompromising adherence to the principle of judicial independence was so vitally necessary:

Advert, sir, to the duties of a Judge. He has to pass between the Government and the man whom that Government is prosecuting: between the most powerful individuals in the community, and the poorest and most unpopular. It is of the last importance, that in the exercise of these duties, he should observe the utmost fairness. Need I press the necessity of this? Does not every man feel that his own personal security and the security of his property depends on that fairness? The Judicial Department comes home in its effects to every man's fireside: it passes on his property, his reputation, his life, his all. Is it not, to the last degree important, that he should be rendered perfectly and completely independent, with nothing to influence or to controul him but God and his conscience? $^{183}$

If judges could be removed at pleasure, he asked,

will any lawyer of distinction come upon your bench? No, Sir. I have always thought, from my earliest youth till now, that the greatest scourge an angry Heaven ever inflicted upon an ungrateful and a sinning people, was an ignorant, a corrupt, or a dependent Judiciary. Will you draw down this curse upon Virginia?"

Marshall's resort to such uncharacteristic rhetorical flourishes showed that the debate over judicial tenure roused his deepest feelings, engaging his mind and heart in equal measure.

${ }^{181}$ Draft of Report of Judiciary Committee (Oct. 12, 1829), in 11 MARSHALL PAPERS, supra note 17, at 279, 279.

${ }^{182}$ Debate on Judiciary (Jan. 13, 1830), in 11 MARSHALl PAPERS, supra note 17 , at 337, 337-38, 341 n.1.

${ }^{183}$ Debate on Judiciary (Dec. 11, 1829), in 11 MARSHALL PAPERS, supra note 17, at $310,311$.

${ }^{184}$ Id. at 317 . 


\section{CONCLUSION}

Marshall's long tenure, spanning the American federal republic's first generations, provided him the opportunity to define-indeed, invent-the office of Chief Justice in ways that his three short-term predecessors could not have done and that foreclosed the same opportunity to his successors. He set standards, established procedures, and created expectations that proved enduring, transcending the unique personal and historical circumstances in which they originated. After Marshall, Supreme Court eras would be known by the names of their Chief Justices. None of his successors has matched his record as the Supreme Court's effective as well as nominal leader. Marshall, writes a recent commentator, was "the prototype of the successful chief justice." ${ }^{185}$ A natural leader, endowed with a keen and supple intellect, an attractive personality, an amiable disposition, a moderate, non-doctrinaire temperament that was amenable to compromise (except on the principle of judicial independence), and a comprehensive knowledge of human affairs, Marshall embodied the qualities that Americans continue to prize in a Chief Justice. As a Court nominee, Marshall lacked "judicial experience," but this was scarcely a disqualification in 1801. Even today, Americans are ambivalent about nominees drawn from the cloistered ranks of the federal judiciary who might be wanting in "real world" experience. ${ }^{186}$

President Adams nominated Marshall to be Chief Justice not simply because his Secretary of State was a distinguished practitioner of law but, more importantly, because this lawyer was a statesman of proven worth, a public servant who had performed in various capacities, legislative and executive, state and federal. In explaining Marshall's successful leadership of the Court, contemporary and presentday commentators have singled out the Virginian's practical, common sense wisdom acquired as a man of affairs. Marshall, wrote a reviewer of Story's eulogy of the Chief Justice, studied "things" rather than "books"; he subjected his opinions "to the test of experience"; he possessed the rare "power of seeing things exactly as they are, without

${ }^{185}$ Jeffrey Rosen, The New Boss, N.Y. Times MAG., Sept. 18, 2005, at 19, 20.

${ }_{186}$ Peter Baker, Alito Nomination Sets Stage for Ideological Battle, WASH. POST, Nov. 1, 2005, at A1. Baker writes, "The same president who touted Miers a month ago as a nominee with real-world experience far removed from 'the judicial monastery' yesterday emphasized Alito's lengthy history on the bench, noting that he 'has more prior judicial experience than any Supreme Court nominee in more than 70 years." $I d$. at A6. 
confusion, distortion or discoloring." 187 Accordingly, Americans should not "regret the hours which Chief Justice Marshall spent in the camp and the senate, or wish that he had rather devoted them to solitary communing with the sages of the law. The wisdom which the former course gave him, was of more importance to his country, than the learning with which the latter might have furnished him." 188 If prior judicial experience has in our time become a prerequisite for a Chief Justice (or any Supreme Court Justice), still the hope is that such a person will also bring a knowledge and experience of the wider world to the task. The Marshall prototype continues to exert its influence in this respect. An admiring twentieth-century Supreme Court Justice gave voice to this sentiment in writing that Marshall's "[e]xperience of men and affairs" as a state legislator, member of Congress, diplomat, and secretary of state "doubtless reinforced a temperament to which abstract theorizing was never congenial." ${ }^{189} \mathrm{He}$ praised Marshall's "hardheaded appreciation of the complexities of government, particularly in a federal system." 190

Marshall commenced his judicial career with a deep understanding of the nature and boundaries of legislative, executive, and judicial power. He remained throughout acutely sensitive to the potential and limits of judicial power in a government that was both republican and federal. A man of the eighteenth century, he believed that popular government could work tolerably well so long as it operated under a constitutional system of checks and balances and produced leaders of excellent character, distinguished for sound and discriminating judgment, and disinterested attachment to the public interest. By 1801, he was doubtful, and in subsequent years became increasingly skeptical, that the legislative and executive-so enmeshed in partisan politics-were by themselves up to the job of maintaining constitutional government. Marshall defined the prerogatives of the office of Chief Justice and exploited them in the firm conviction that the judicial branch was the best hope for preserving the orderly and virtuous republic. More than anyone, he was responsible for implanting the perception of the Supreme Court as an impartial umpire standing above the partisan fray, a repository of wisdom and virtue, where rea-

${ }^{187}$ Chief Justice Marshall, 42 N. AM. REv. 217, 225 (1836), available at http:// cdl.library.cornell.edu/cgi-bin/moa/sgml/moa-idx?notisid=ABQ7578-0042-11.

${ }^{188} I d$. at 226.

${ }^{189}$ Felix Frankfurter, John Marshall and the Judicial Function, in THAYER, HOLMES, AND FRANKFURTER ON MARSHALL, supra note 1, at 145.

${ }^{190} I d$. 
son, reflection, and disinterested judgment hold sway. This perception, the product of an eighteenth-century sensibility, has essentially survived into the twenty-first century and remains Marshall's greatest legacy. 